\title{
グラム陽性細菌の薬剤耐性と感染制御
}

\author{
野口雅久
}

\section{Antimicrobial Resistance and Infection Control for Gram-positive Bacteria}

\author{
Norihisa Noguchi \\ Department of Microbiology, School of Pharmacy, Tokyo University of Pharmacy \\ and Life Sciences; 1432-1 Horinouchi, Hachioji, Tokyo 192-0392, Japan.
}

(Received October 8, 2020)

\begin{abstract}
Antimicrobial resistance (AMR) is a serious problem worldwide. We searched for the AMR determinants of various bacteria isolated from clinical settings and studied their resistance mechanisms and molecular epidemiology. This review focuses on the AMR of Staphylococcus aureus, a major gram-positive pathogen, which has the ability to acquire resistance to antimicrobials. The resistance factors of $S$. aureus are frequently found on mobile elements, including plasmids and transposons. We determined the complete DNA sequence of the tetracycline-resistance plasmid and found that the inducible expression of tet $K$ in $S$. aureus was regulated by a post-transcriptional attenuation mechanism. Furthermore, outbreaks of methicillin-resistant $S$. aureus (MRSA) in hospitals and communities have led us to study infection controls, including the antiseptic susceptibility evaluation and molecular epidemiology of MRSA. Various antiseptic resistance determinants, such as $q a c A / B$ and $s m r$, were identified on plasmids and characterized. We demonstrated that the plasmid-mediated efflux pump QacB variant QacIII confers fluoroquinolone efflux ability to $S$. aureus. Studies on MRSA epidemiology had shown that community-acquired MRSA (CA-MRSA) was disseminated into hospitals and that an increased use of alcohol-based rubs could reduce the incidence of MRSA infections in such institutions. Additionally, the study of CA-MRSA collected from communities and hospitals showed an increase in Panton-Valentine leucocidin (PVL) -positive CA-MRSA, causing severe skin and soft tissue infections. Moreover, various PVL-positive CAMRSA clones have disseminated in Japan, whereas the USA300 LV/J clone evolved in that country. Our study provides important information regarding MRSA infection control.
\end{abstract}

Key words__antimicrobial resistance; Staphylococcus aureus; plasmid; infection control

\section{はじめに}

筆者は, 細菌の薬剤耐性と感染制御に関する研究 を DNA 解析の手法を用いて行ってきた。これら は，病院やクリニックの患者（臨床）から分離され た黄色ブドウ球菌, 肺炎球菌, ヘリコバクター・ピ ロリ，大腸菌，緑膿菌，アクネ菌などから薬剂耐性 遺伝子を検索して，遺伝子の同定，耐性機序と耐性 伝播の解明，薬剤感受性試験による有効な抗菌薬の 検索等により, 感染症治療と感染制御の一助となる 医療系の研究であり，当時の基礎薬学系では異端で あった。本総説は, 2019 年度退職にあたり在職中

東京薬科大学薬学部病原微生物学教室（广192-0392 東 京都八王子市堀之内 1432-1)

e-mail: noguchin@toyaku.ac.jp

本総説は, 2019 年度退職にあたり在職中の業績を中心 に記述したものである.
の研究, 黄色ブドウ球菌を代表とするグラム陽性菌 の薬剤耐性の変遷について, 筆者の研究の歩みとと もに記述する.

\section{1. 黄色ブドウ球菌}

黄色ブドウ球菌（Staphylococcus aureus）は，グ ラム陽性球菌でコアグラーゼを産生する. ${ }^{1)} 16 \mathrm{~S}$ rRNA 塩基配列に基づく系統分類では，ファーミ キューテス門，バシラス網，バシラス目，ブドウ球 菌科に属する．本菌は毒素のデパートと称され，表 皮剥脱毒素，エンテロトキシン，溶血毒素，白血球 破壊毒素, 毒素性ショック症候群毒素などの種々の 毒素や病原性因子を産生する菌株が存在する。 その ため, 約 49 種のブドウ球菌の中で最も病原性が高 い. 通常, ヒト由来コアグラーゼ陽性菌はほとんど が黄色ブドウ球菌であることから，臨床では，便宜 上，コアグラーゼ陽性ブドウ球菌 (黄色ブドウ球菌) 
とコアグラーゼ陰性ブドウ球菌（coagulase negative staphylococci；CNS）に二分されている．代表的な 化膿性疾患の起炎菌であり，産生する毒素によって 食中毒，皮膚・軟部組織感染症，肺炎，敗血症など 様々な感染症に関与する。一方，皮膚常在菌として も知られ，約 $30 \%$ の健常者の鼻腔内からも分離さ れる。薬剤耐性を獲得し易く, 代表的な院内感染原 因菌として，本菌の流行が院内感染の指標となって いる.

\section{2. 黄色ブドウ球菌の薬剤耐性プラスミド}

学部学生時に, 米国カリフォルニアのスタン フォード大学を中心に DNA 組換え実験が発表され た。組換え DNA 実験の潜在的な危険性（バイオハ ザード）が指摘され，1975 年に科学者自らが研究 を制限し，社会的責任を問うたことで科学史に残る

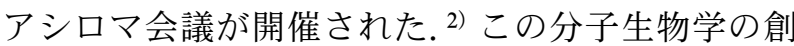
成期に, 組換え DNA 研究を知り，研究者の道を志 した。ところが，1970 年代において，薬系大学で はDNA を研究していたのは主に有機化学系の研究 室であった。1976 年, 東京薬科大学は女子部と男 子部が八王子キャンパスに移転したが，これにより 偶然，女子部の第二微生物学教室（現：病原微生物 学教室）の笹津備規先生らが黄色ブドウ球菌の薬剤 耐性プラスミドを用いて枯草菌（Bacillus subtilis） を形質転換したことが話題となっていたことを知つ た. ${ }^{3)}$ そこで，この教室の大学院生になり，黄色ブ ドウ球菌の薬剤耐性の研究を始めた。

当時は，プラスミド DNA を遺伝情報などの生物 活性を持つ完全な分子として精製する技術や情報が 未成熟であった。そのため，放射性物質で DNA を 標識後, 密度平衡勾配遠心によって分離, 標識され たプラスミド DNA 分画を集め，透過型電子顕微鏡 でプラスミド分子を確認して，大きさを測定すると いった煩雑な方法が取られ，1 カ月ほど要してい た。その精製したプラスミドを枯草菌に取り込ま せ，耐性を発現させた実験は，プラスミド DNA が 生物活性を持つことを証明した画期的な実験であつ た. ${ }^{3,4)}$ しかし，薬剤耐性プラスミドの遺伝子構造を 解析することは非常に困難であったため, 病原細菌 の遺伝子を用いることの安全性が危惧されていた. そこで，黄色ブドウ球菌の薬剤耐性プラスミドをグ ラム陽性菌における安全なべクターとして開発する ため，制限酵素を含めた DNA 関連酵素を研究して
いた理化学研究所（理研）の安藤忠彦主任の微生物 学研究室の研究生になることを条件に博士課程に進 学した。理研では，アシロマ会議に参加した宍戸和 夫先生（東京工業大学名誉教授）から直接指導を受 けた.

\section{3. 薬剤耐性プラスミドのゲノム解析}

理研において, 黄色ブドウ球菌の小型のテトラサ イクリン（tetracycline; TC）耐性プラスミド pTZ5 （旧名：pTP-5）の遺伝子解析に取り組んだ。当時 は，DNA 塩基配列決定法は普及しておらず，解析 を行う第 1 段階として，制限酵素の地図作成を行つ

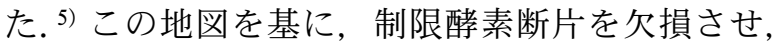
それらを枯草菌に導入し， $\mathrm{TC}$ 耐性発現とプラスミ ドの細胞内保持（複製能）を調べ，TC 而性遺伝子 と複製遺伝子をマッピングした。同時に生物活性を 有する最小の $\mathrm{TC}$ 耐性プラスミド pNS1 を作製した (Fig. 1) . ${ }^{5)}$ Maxam と Gilbert の化学分解による DNA 塩基配列決定法が発表され，理研において， DNA 塩基配列決定法のシステム構築と pNS1 の全 塩基配列決定の研究を開始した。 Maxam・Gilbert 法は，制限醳素切断末端から 200-300 塩基しか決定 できず，解析した塩基配列は穴だらけであったが， サンガーが開発した Dideoxy 法を併用することで 3 年を要して, 全塩基配列を決定した。 ${ }^{6)}$ ところが, いち早く，米国のKhon らが TC 耐性プラスミド pT181（4.4 kb）の全塩基配列を発表した. ${ }^{7)}$ pNS1 は pT181 と $99.5 \% の$ 相同性を示していたため，競 争には負けてしまった。しかし，彼らの報告した $\mathrm{TC}$ 耐性遺伝子 tet $K$ は 1 塩基の間違いがあり，のち に筆者の tet $K$ が正しいことが証明された。tetKの 発現は TCによって誘導される。 大腸菌の tet $A$, tetB などはラクトースオペロンと同様に, tet 構造 遺伝子上流に存在する調節遺伝子 tet $R$ から産生さ れるリプレッサーによって負の転写制御を受けてい る.しかし，黄色ブドウ球菌で見つかったマクロラ イド耐性遺伝子 erm $C$, クロラムフェニコール耐性

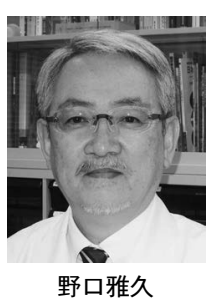

1978 年東京薬科大学卒業後, 同大学大 学院院進学, 理化学研究所研究生. 83 年博士課程修了, 薬学博士取得. 同年 同大学助手, Maryland 大学留学, 講 師，准教授を経て，2012 年病原微生物 学教室教授. 20 年名誉教授, 同大学客 員教授, 明星大学理工学部非常勤講師。 


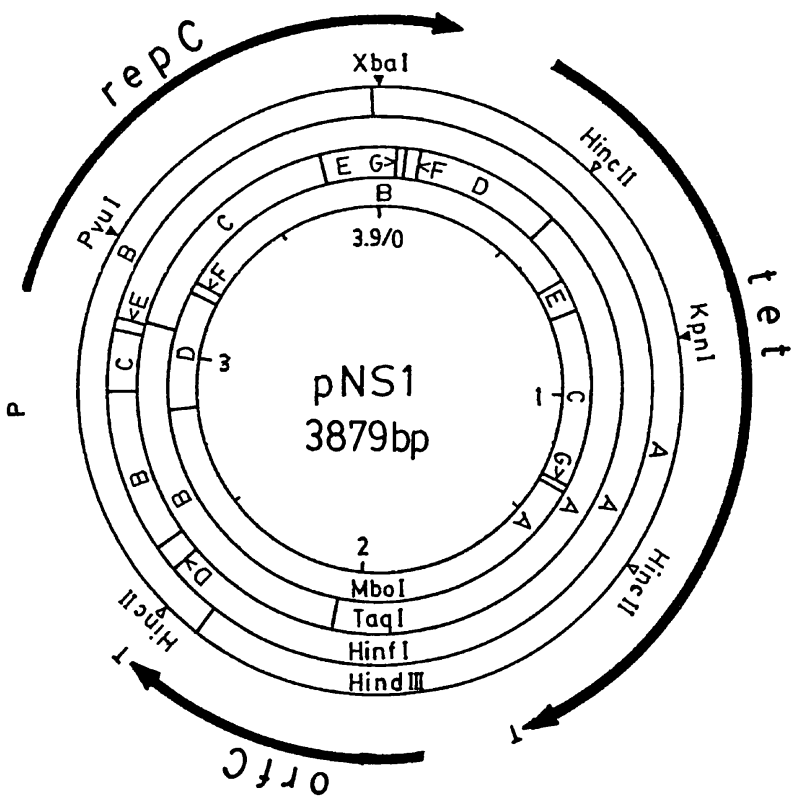

Fig. 1. Restriction and Gene Maps of Plasmid pNS1

Arrows show gene regions and transcription direction. P, promoter; T, terminator; tet, tetracycline-resistance gene tet $K$; repC, replication gene; orfC, open reading frame $\mathrm{C}$.

遺伝子 cat や TC 耐性遺伝子 tet $K$ などは, リプレッ サーをコードする調節遺伝子が存在しない. ${ }^{8-10)}$ 代 わりに，構造遺伝子上流に，小さなペプチドをコー ドするリーダー遺伝子とヘアピン構造を形成可能な
塩基配列が存在した（Fig. 2)。調節は，転写でな $<$, tet $K$-mRNA が特異的なコンフォメーション構 造を形成し, tet $K$ 構造遺伝子のリボソーム結合部 位 (ribosome-binding site; RBS) 2 がマスクされる. その結果, リボソームの結合が阻害され，さらに裸 の tetK-mRNA の分解が進行し, TetK タンパク質 の合成が抑制される。TCがリボソームに結合して リーダー領域のタンパク質合成を阻害すると, tet $K$-mRNA のコンフォメーションが変化し，tetK 構造遺伝子のリボソーム結合部位（RBS2）が露出 し，リボソームが結合して，TetK のタンパク質合 成が進行する，筆者は，ermCや cat86で提唱され た posttranslational attenuation mechanism に類似 していること明らかにした9,10)。さらに，これらの 手法を用いて，クロラムフェニコール耐性プラスミ ド pTZ12，アミノグリコシド耐性遺伝子 $a a d K ， マ$ クロライドリン酸化酵素 $m p h A$ などの遺伝子を見 つけ，その遺伝子構造と耐性メカニズムを明らかに

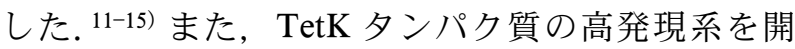
発し, TetK タンパク質の構造の解明に貢献し た. ${ }^{16,17)}$ これらの耐性遺伝子とプラスミドを組換え て，グラム陽性菌のベクターや大腸菌とのシャトル ベクターを構築した. ${ }^{11,18-20)}$

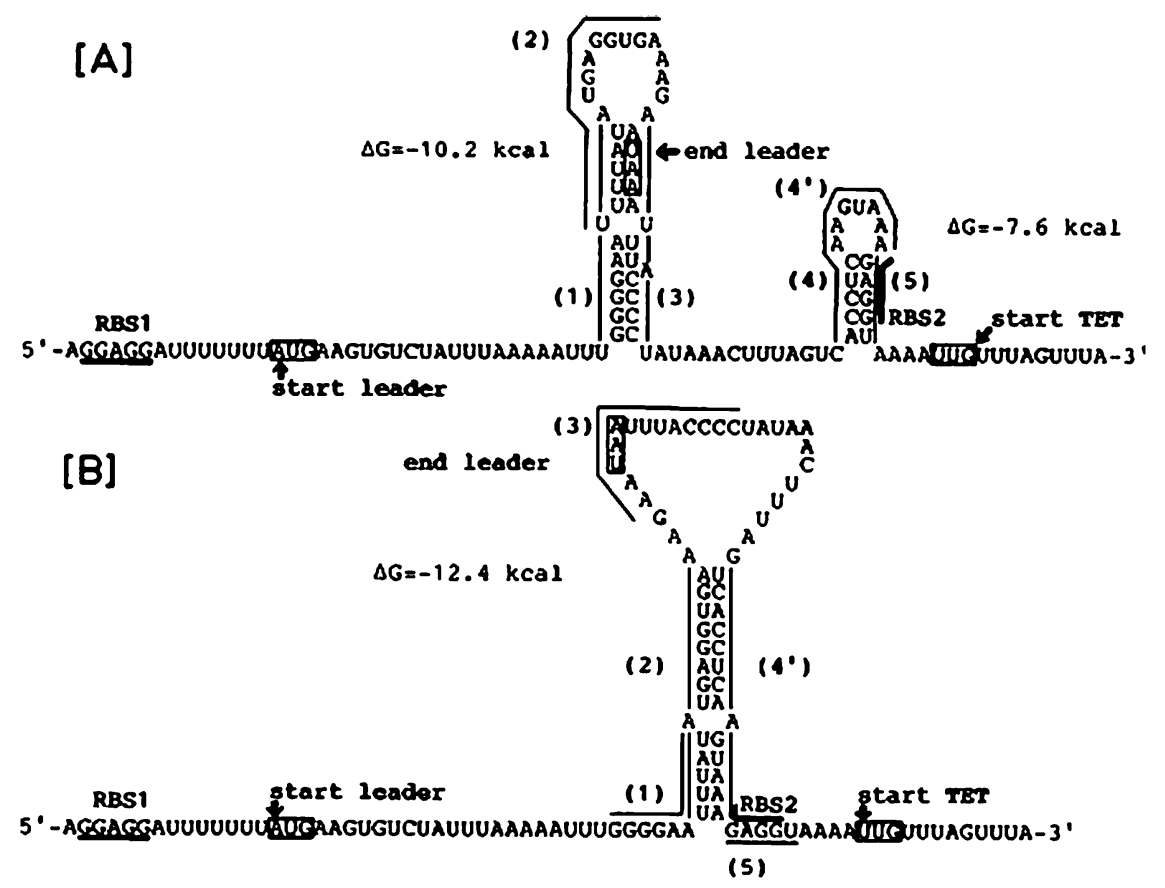

Fig. 2. Hypothetical Secondary Structure of the Control Region of the tet $(\mathrm{K})$ mRNA 5-end

The mRNA sequence was deduced from pNS1 DNA sequence. $\left.{ }^{6}\right)$ Structures $[\mathrm{A}]$, and $[\mathrm{B}]$ correspond to the inactive and active forms, respectively. RBS1 and SBS2 refer to the ribosome binding sites for the translation of the leader and the tetracycline-resistance protein (TET), respectively. 
1989 年, Bacillus 属由来誘導性クロラムフェニ コール耐性遺伝子 cat86 の発現を研究していた Maryland 大学の Lovett 教授の下にポスドクとして 留学し, cat の遺伝子発現を研究する機会が得られ た.この研究で，枯草菌では終止コドンUGA がト リプトファンとして解読される readthrough 現象を 明らかとし, 21) 20 年後の筋ジストロフィー薬の開発 研究につながつた. ${ }^{22}$

一方，枯草菌 ATCC6633 は，抗菌薬に感受性と して知られ，抗生物質の力価検定の標準株として使 用されている。ところが，ストレプトマイシンをわ ずかに不活化することを見い出した. ${ }^{23)}$ 枯草菌の染 色体上における薬剂耐性遺伝子の検索を行い, アミ ノグリコシド不活化酵素をコードする遺伝子 $a a d K$ をクローニングし，それらの遺伝子マップを含めた 遺伝子を同定した. ${ }^{13,24)}$ その後, 枯草菌の全ゲノム シーケンスが決定され，筆者の結果がサポートされ た。また，相同性組換えを応用した insertion inactivation 法で作製した knockout 株は，ストレプトマ

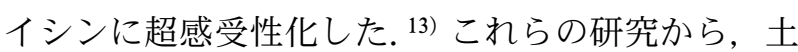
壌細菌が薬剤耐性関連遺伝子の拡散におけるリザー バーとなつている可能性が示された。

\section{4. プラスミド性消毒薬低度耐性遺伝子の解析}

1990 年頃から，日本の院内でセフェム系薬に耐 性を示す多剤耐性黄色ブドウ球菌，いわゆるメチシ リン耐性黄色ブドウ球菌（methicillin-resistant Staphylococcus aureus; MRSA）の院内感染が大き な問題となってきた. ${ }^{1)}$ 細菌の院内感染を制御する ために，消毒は重要な手段である，汎用される四級 アンモニウム化合物 (quaternary ammonium compounds；QACs）に抵抗性を示す小さな消毒薬耐性 遺伝子 $s m r$ (旧名：qacC） を見い出した. ${ }^{25)} s m r$ は 両端に繰り返し配列を有する転移可能な力セット構 造をしていた。 その後， $s m r$ 類似遺伝子が，様々な バクテリアから見い出された， $s m r$ を有するブドウ 球菌は QACs に対して低感受性を示すが，その抵 抗性は弱く，本来の機能は不明である，これらの消 毒薬低度耐性は，実臨床における消毒薬濃度では十 分に殺菌可能である，そのため，現在では消毒薬低 度耐性遺伝子と称されている. ブドウ球菌の消毒薬 低度耐性は，それらの遺伝子がコードする薬物の排 出ポンプによる. プラスミド性の消毒薬低度耐性遺 伝子を研究中, $q a c や s m r$ を保有しない黄色ブドウ
球菌において，消毒薬の感受性が低下した株が複数

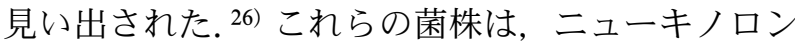
系薬のノルフロキサシンに耐性であった。 そこで, ノルフロキサシンを排出するポンプをコードする遺 伝子 $\operatorname{nor} A$ 領域を解析したところ, これらの株は $\operatorname{nor} A$ 上流のプロモータ一領域に変異を有し， nor $A$ の転写発現六進によって消毒薬にも低度耐性を示し た. ${ }^{27,28)} \operatorname{nor} A$ は, 12 回膜貫通型薬剤排出ポンプを コードする多剤耐性遺伝子であった。このnor $A$ 転 写六進の変異は，ノルフロキサシンよりも色素や消 毒薬によって高頻度に出現することを明らかとし， 環境中の抗微生物薬が多剂耐性変異を誘発する可能

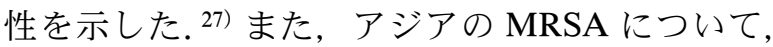
消毒薬低度耐性遺伝子 $q a c A / B$ や $s m r$ の分布を調 査したところ，インドネシアを除く，ほとんどの国 から消毒薬低度耐性遺伝子を保有する黄色ブドウ球 菌が分離され，アジアに拡散していることを明らか とした. ${ }^{29)}$ 一方，日本には，殺菌薬である消毒薬の 感受性を評価する標準法がなかった。 そこで，消毒 薬に対する感受性を様々な方法で測定するととも に，標準法の開発に取り組み，中和剤を添加する time killing 法を開発した. ${ }^{30,31)}$

さらに，qacA/Bが，消毒薬感受性の特性や DNA シーケンス等から少なくとも 5 つのサブグ ループに分かれ（Fig. 3)，qacBIII はグラム陽性菌 では初めてとなるプラスミド性のキノロン耐性因子 であることを明らかとした. ${ }^{32,33)}$ 大学病院の薬剂部 と共同研究を行い， $q a c A / B$ 陽性株を含めた院内に おける MRSA の分布と消毒薬の使用量を解析し た. ${ }^{34)}$ その結果，アルコールベース手指消毒薬の導 入と使用量の増加に伴い, MRSA 感染症が減少し たことを明らかとした。

筆者が分離した $q a c A / B$ 保有株は，理研微生物材 料開発室に寄託し，ブドウ球菌の消毒薬低度耐性遺 伝子の標準株として利用されている.

\section{5. 感染制御に関する臨床研究}

前後するが，2000 年を目の前にして，筆者の所 属教室が基礎薬学系から大学院医療薬学系に所属変 更となり，研究を臨床系にシフトした。姉妹校で あつた東京医科大学八王子医療センターにおいて, 院内感染症対策委員会が設置され，院内環境の細菌 学的調査研究を開始した。 2000 年頃は, 病院の環 境細菌を調査しても無意味だ，という考えが学会を 


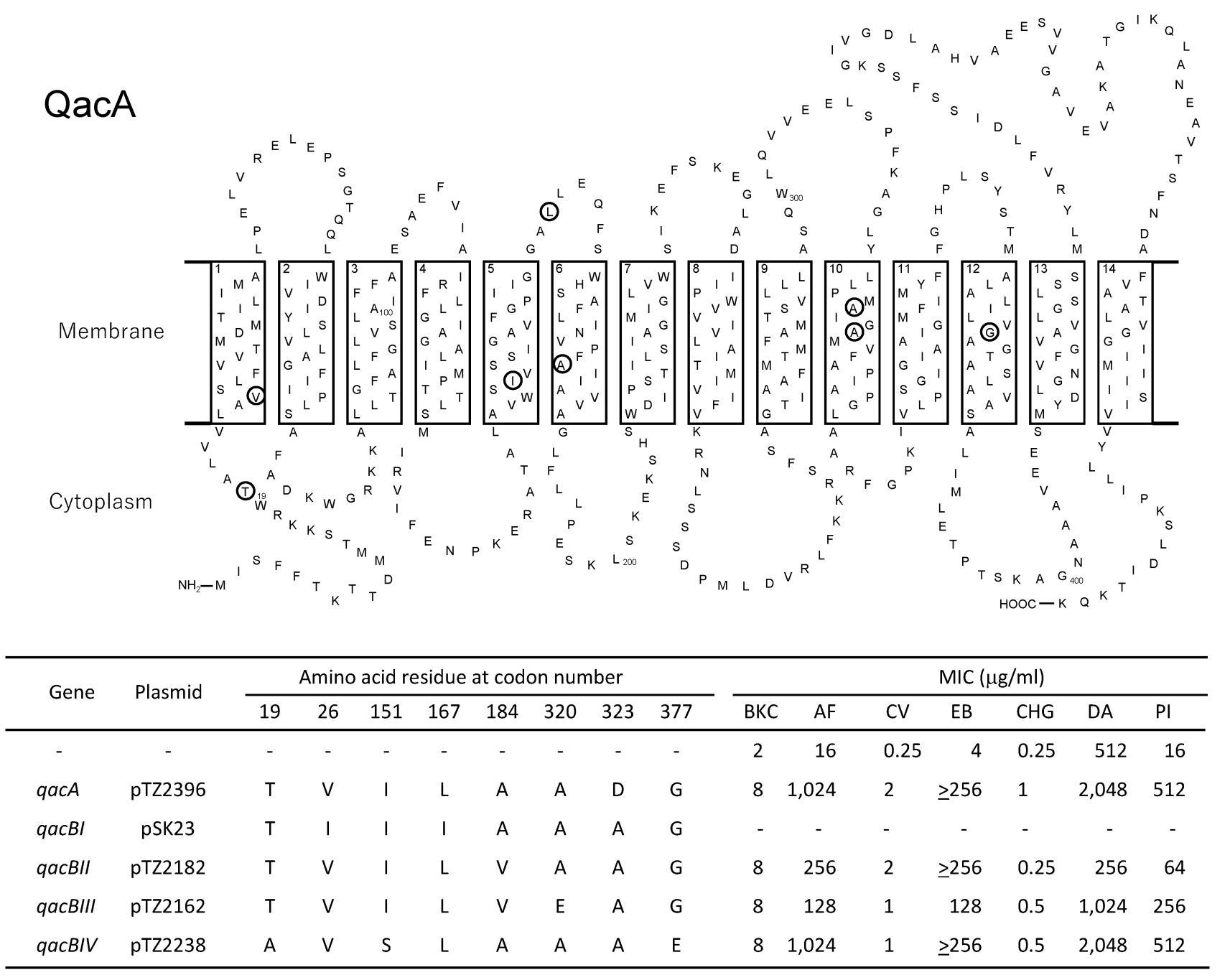

Fig. 3. Transmembrane Structure of QcaA, and Antiseptic Susceptibility of Staphylococcus aureus Carrying the qacA/B Genes

MIC, minimum inhibitory concentration; AF, acriflavin; BKC, benzalkonium chloride; $\mathrm{CHG}$, chlorhexidine digluconate; CV, crystal violet; DA, diminazene aceturate; EB, ethidium bromide; PI, pentamidine isethionate; -, none; A, alanine; D, aspartic acid; E, glutamic acid; G, glycine; I, isoleucine; S, serine; T, threonine; V, valine. The amino acid sequence of QacBI of pSK23 was obtained from Paulsen et al. ${ }^{33)}$

占めていた。 しかし, 環境細菌の研究で, 院内感染 の原因菌である MRSA はドアノブ，キーボードな ど人が触れる場所に, 一方, 緑膿菌は湿潤したシン クや便器など，その細菌が好む環境に高頻度で存在 することや，院内の病原性細菌が，医療従事者を含 むヒトを介して移動しているエビデンスを明らかに した. ${ }^{35,36)} こ の$ 頃, 厚生労働省が院内及び地域の感 染対策を奨励し，西多摩 Infection Control Forum として, 西多摩医療圏における感染制御ネットワー クが設立された，筆者は，その代表世話人会のメン バーとなり, 参加病院から MRSA な゙゙の薬剂耐性 菌が本学に収集され，西多摩医療圏の院内感染を監 視するシステムを構築した。 約 5 年を要したが, 東 京医科大学八王子医療センターから始まり, 東海大
学医学部付属八王子病院, 日本医科大学多摩永山病 院，国立病院機構災害医療センターなど 10 施設の 基幹病院から年間約 800 株以上もの臨床分離細菌の 提供を受けている。特に，立川の災害医療センター で発生した多剂耐性緑膿菌（multi-drug resistant Pseudomonas aeruginosa; MDRP) のアウトブレイ クに際し, 遺伝子解析を行うことで事態の収束に貢 献した.

薬学部が 6 年制となり, 病院実習では病棟業務の ウエイトが大きくなつた。これに伴い，実習生が患 者や他の医療従事者と接する機会が増加し，実習後 の薬学生の鼻腔からメチシリン耐性表皮ブドウ球菌 (methicillin-resistant Staphylococcus epidermidis; MRSE）が高頻度に分離されることが分かってき 
た。そこで，薬学生，薬剤師，医師，看護師などの 医療従事者の手指常在菌を調査したところ，MRSE が高頻度に定着していることが分かった. ${ }^{37)} こ の$ 結 果を踏まえ，実際に種々の手指消毒薬を用いた手洗 いによる消毒効果を測定した. ${ }^{38-40)}$ このような研究 は，基礎薬学からすると，研究でなく検査とみられ るが，抗菌薬の適正使用に関する情報を収集・サー ベイランスし，それらを実験的に証明する研究は， 今後, 医療に携わる薬学分野において，教育を含め て重要と考える.むしろ, 現在の日本の医療薬学に 欠けている分野ではないかと感じている.

話は変わるが，ブドウ球菌属のStaphylococcus lugdunensis は，コアグラーゼ陰性であるが，病原 性が黄色ブドウ球菌に類似して高いことで注目され ている. タンニンを分解するタンナーゼを産生する レンサ球菌 Streptococcus gallolyticus subsp. gallolyticus は，大腸がんとの関連性が指摘されてい る. そこで, 東京医科大学病院の消化器内科と共同 で，大腸がん患者の直腸ぬぐいスワブ又は便から夕 ンナーゼ産生菌の分離を試みたところ，アデノーマ の患者において，St. gallolyticus でなく，タンナー ゼを産生する S. lugdunensis の分離頻度が有意に高 く，その菌株はある特定の遺伝子タイプの菌株であ ることを見い出した. ${ }^{41,42)}$ しかし，タンナーゼ産生 菌と大腸がんの関連性は不明のままである。

\section{6. 市中型 MRSA と皮膚感染症}

当初, MRSA は抗菌薬が汎用されている病院内 でのみ流行すると考えられていた。ところが，一般 の健常者（市中）や幼稚園児などの小児からも MRSA が分離されるようになってきた，病院と市 中で分離される MRSA は，薬剤感受性， mecA が 存在する staphylococcal cassette chromosome (SCC) mec のタイプ，菌株の遺伝子型，保有する毒素遺伝 子などが大きく異なる。そのため，前者は院内型 MRSA (hospital-acquired MRSA; HA-MRSA), 後 者は市中型 MRSA（community-acquired MRSA; CA-MRSA）と呼ばれている，特に，CA-MRSA の 中でも, 強力な白血球破壞毒素である PantonValentine leukocidin（PVL）を産生する株による重 症皮膚感染症が，欧米を中心に大学の運動部や刑務 所内で流行し，深刻な問題となっていた。 そこで， 市中の表在性皮膚感染症で小児に好発する伝染性膿 痂疹（トビヒ）由来の黄色ブドウ球菌に関する研究
を，当時関西医科大学香里病院皮膚科准教授の西嶋 摂子先生とスタートした。興味深いことに，日本で は CA-MRSA から PVL 遺伝子や消毒薬低度耐性遺 伝子 $q a c A / B$ が検出されなかった. ${ }^{43)}$ 特に，臨床医 である西嶋先生の経験から，トビヒには消毒薬が効 くという考えに合致した。臨床医のネットワークは 非常に強 $<$, 高松赤十字病院の皮膚科部長池田政身 先生を介し，高松市周辺の皮膚科クリニックから， そして, 北海道, 青森, 秋田, 新潟, 神奈川, 多摩 地区，九州地区，沖縄（石垣島）から検体の提供が 広がった。このような全国規模の疫学研究によっ て，黄色ブドウ球菌による皮膚感染症の約 $25 \%$ が MRSA に起因していること，2014 年頃から日本に は少ないと考えられていた PVL 陽性 MRSA が急 増し，その多くが米国で大流行している USA300 clone という遺伝子型であることを明らかにし

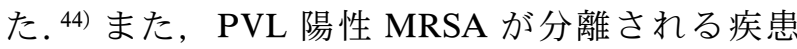
は，せつ，よう，蜂窩織炎などの深在性皮膚疾患で あったことから，PVLが皮膚感染症の重症化に寄 与していることが強く示唆された.

一方で, 病院内で分離される MRSA において, 従来の HA-MRSA の割合が大きく減少し，CAMRSA の割合が急増していることが分かってき

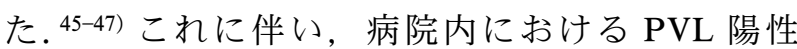
MRSA の分離頻度も増加していることが明らかと なった。 ${ }^{47,48)}$ また，院内の PVL 陽性株は市中の菌 株よりも多様性を示し，USA300 clone を中心に少 なくとも 7 種の clones が流行していることが明ら かとなった. ${ }^{49-51)}$ それらのうち，全ゲノム解析から， USA300-LV/J clone と $\Psi$ USA300 clone は, 日本で 独自に進化した PVL 陽性 MRSA であることが示 唆された. ${ }^{49,51)}$ さらに，これまでに収集した PVL 陽性 MRSAの各種抗菌薬感受性を測定し，抗 MRSA 薬に加え，皮膚科領域で汎用される経口抗 菌薬ミノサイクリンも有効である可能性を提示し た. ${ }^{44,48)}$

この間，2018 年には，西多摩 Infection Control Forum の関連病院で生じた院内感染のアウトブレ イクが，PVL 陽性 MRSA に起因することを明らか とし，直ちに隔離等の感染対策が実施され，その後 のアウトブレイクの阻止に貢献した. ${ }^{52)}$ さらに，近 隣大学の運動部員において重症皮膚軟部組織感染症 が発生した際，起炎菌が PVL 陽性 MRSA である 
ことを迅速に同定した。これにより，同運動部員が 同居していた寮生の鼻腔内検査が実施され，PVL 陽性 MRSA 保菌者の除菌及び寮内の消毒と手指衛 生の徹底が速やかに行われ，その後の感染拡大の防 止に貢献した. ${ }^{53,54)}$ 臨床と基礎との連携は, 今後の 薬学教育並びに医療研究に必要なことと考える．当 初，PVL 陽性 MRSA 感染症患者のほとんどが米軍 関係者又は渡航経験者であったが，最近は，海外渡 航経験のない日本人から分離されるようになってい る.オリンピックを前に，PVL 陽性 MRSA には注 視する必要がある.

\section{7.ざ瘡治療と薬剤耐性アクネ菌}

ブドウ球菌ではないが，皮膚常在グラム陽性のア クネ菌（Cutibacterium acnes）について記述する. トビヒを研究中，日本の尋常性ざ瘡（二キビ）の治 療ガイドラインが設定された。 ${ }^{55)}$ ざ瘡のうち，炎症 性ざ瘡は，面皰（二キビ）内でのアクネ菌の過剩増 殖が一因となっている，そのため，アクネ菌の増殖 抑制を目的として，クリンダマイシンなどの外用抗 菌薬，及びマクロライド系のロキシスロマイシン, $\mathrm{TC}$ 系のドキシサイクリンやミノサイクリンなどの 経口抗菌薬が使用されている，驚くべきことに，ざ 瘡は非感染性疾患であるにもかかわらず，数力月か ら数年にわたつた長期の抗菌薬処方が行われてい る，そこで，日本の現状を調査するため，ざ瘡研究 会の皮膚科医の協力により, 病院と全国の皮膚科ク リニックからざ瘡検体の提供を受け，日本のざ瘡由 来アクネ菌の薬剤耐性を調查した. ${ }^{56,57)}$ その結果, 2013-2015 年に病院の皮膚科外来患者から分離され たアクネ菌の $44.3 \%$ が，ざ瘡治療で汎用されるク リンダマイシンに耐性を示した。ささらに，経口抗菌 薬ロキシスロマイシンを服用している患者では，交 差耐性を示すクリンダマイシンの耐性菌分離率が非 常に高かった. ${ }^{58)}$ 遺伝子解析から, アクネ菌の遺伝 子型は患者毎に異なり，菌の伝播でなく，個々の患

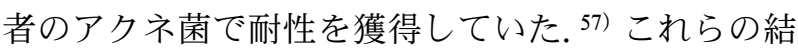
果は，抗菌薬の不適切な使用が薬剂耐性アクネ菌を 出現・拡大させていることを示している，薬剤耐性 (antimicrobial resistance; AMR) グローバル・アク ション・プランと相まって, 新ざ瘡治療ガイドライ ンでは薬剤耐性菌出現の回避が治療指針の 1 つとさ れ，長期の抗菌薬使用は避けることを推奨してい る.さらに，耐性遺伝子の解析から，アクネ菌の薬
剂耐性は薬剂標的部位の変異であったが，一部のク リンダマイシン耐性はクリンダマイシン・マクロラ イド系薬の標的部位をメチル化する酵素をコードす る高度耐性遺伝子 erm の獲得であった。特に，筆 者が初めて発見した erm (50) は，伝達性プラスミ ド pTZC1 上にコードされていた. ${ }^{59)}$ pTZC1 は，ク リンダマイシン・マクロライド系薬に高度耐性化す る遺伝子に加え， $\mathrm{TC}$ 耐性遺伝子 tet $W$ もコードし ているため，本プラスミドの伝播・拡大に注視する 必要がある.

\section{8. 抗感染症薬の探索}

国際交流として，中国の長春中医薬学大学を 4 回 ほど訪問し，身体と処方薬の総合的な作用による未 病を目的とした中医学を体験した。そこで，2015 年頃から，中医学や漢方による処方薬について，抗 菌活性に加え，毒素産生やバイオフィルム形成など の病原因子に対する抑制効果を有する処方薬の探索 を行った。経験的に感染症治療に用いられる処方薬 の中から，抗感染症作用を有する薬剂を見い出し た. ${ }^{60-64)}$ 特に，皮膚の湿疹や皮膚炎に使用される当 帰飲子は，表皮ブドウ球菌と PVL 陽性 MRSA の 共培養下，表皮ブドウ球菌の増殖を阻害することな $く$, PVL 陽性 MRSA の増殖と PVL 産生を特異的 に抑制することを見い出した。 ${ }^{62)} \mathrm{PVL}$ 産生の抑制 は，PVL の遺伝子発現に関与するアクセサリー調 節遺伝子の抑制であった。このように，常在菌に対 する作用は弱く，病原細菌に特異的に抗感染症作用 を有する薬剤は，薬剤耐性菌の出現を抑制し，感染 症治療の補助薬として有用であると考える，経験則 を実証することで, 薬の育薬に貢献できればと考え ている.

\section{おわりに}

AMR 対策は，感染症全般に係わり，重要であ る。本総説における, 疫学解析や症例等に関する デー夕は引用文献を参考にして頂きたい，薬剤耐性 は，抗菌薬の適正使用に深く係わっており，薬剤師 及び薬剤師を育成する薬系大学が主体となって係わ ることができる研究と考える。それらの研究でネッ トワークが構築できれば，抗微生物薬の適正使用や 安全管理に貢献できると考える。 また，これまでの 薬剂耐性の研究は, 個々の臨床分離細菌について解 析してきた. しかし，調査した院内感染や市中感染 を振り返ると, 病院あるいは地域の環境（建築工事 
や造成, 気候), 人（入院患者）の移動，新薬の導 入や抗菌薬の使用などが変化すると, 感染症のアウ トブレイクが発生している事例があった。 人工知能 （artificial intelligence; AI）の時代である。研究視 点を高くし, 病院全体の多様性の変化について, 病 院に眠っている臨床データを精査し，アウトブレイ クを誘発する院内環境因子を見い出し，これらの因 子の変動から感染症の流行を予測・防止するような 研究が, 今後, 重要ではないかと考える.また, 薬 局のデー夕を活用し，上市されている感染症以外の 薬剤の使用による感染症発症の低下などを発見でき れば，新たな感染症治療として育薬できるのではな いだろうか. 臨床は, 研究課題の宝庫であり, 基礎 薬学と臨床が連携することで, 薬学研究が発展する ことを期待する。

\section{謝辞本総説で紹介した研究は, 東京薬科大学} 病原微生物学教室の卒論生, 大学院生及び職員の協 力によって行われたものであり，心から謝意を表 す。また，研究に賛同頂いた医師や臨床検査技師の 方々による臨床検体及び臨床分離細菌提供の厚意に 感謝する.

利益相反＼cjkstart開示すべき利益相反はない.

\section{REFERENCES}

1) Lakhundi S., Zhang K., Clin. Microbiol. Rev., 31, e00020-18 (2018).

2) Berg P., Baltimore D., Brenner S., Roblin R. O. III, Singer M. F., Proc. Natl. Acad. Sci. USA, 72, 1981-1984 (1975).

3) Kono M., Sasatsu M., Hamashima H., Microbios Lett., 5, 55-59 (1977).

4) Ehrlich S. D., Proc. Natl. Acad. Sci. USA, 74, 1680-1682 (1977).

5) Noguchi N., Shishido K., Ando T., Kono M., Gene, 21, 105-110 (1983).

6) Noguchi N., Aoki T., Sasatsu M., Kono M., Shishido K., Ando T., FEMS Microbiol. Lett., 37, 283-288 (1986).

7) Khan S. A., Novick R. P., Plasmid, 10, 251259 (1983).

8) Aoki T., Noguchi N., Sasatsu M., Kono M., Gene, 51, 107-111 (1987).

9) Mayford M., Weisblum B., EMBO J., 8,
4307-4314 (1989).

10) Lovett P. S., Gene, 179, 157-162 (1996).

11) Kono M., Aoki T., Sasatsu M., Noguchi N., O'hara K., Agric. Biol. Chem., 49, 1429-1433 (1985).

12) Noguchi N., Ohmiya K., Tanaka T., O'hara K., Kono M., Agric. Biol. Chem., 53, 25192520 (1989).

13) Noguchi N., Sasatsu M., Kono M., FEMS Microbiol. Lett., 114, 47-52 (1993).

14) Noguchi N., Emura A., Matsuyama H., O’Hara K., Sasatsu M., Kono M., Antimicrob. Agents Chemother., 39, 2359-2363 (1995) .

15) Noguchi N., Katayama J., O'Hara K., FEMS Microbiol. Lett., 144, 197-202 (1996).

16) Noguchi N., Emura A., Sasatsu M., Kono M., Biol. Pharm. Bull., 17, 352-355 (1994).

17) Yamaguchi A., Shiina Y., Fujihira E., Sawai T., Noguchi N., Sasatsu M., FEBS Lett., 365, 193-197 (1995).

18) Kono M., Noguchi N., Sasatsu M., Agric. Biol. Chem., 47, 2393-2394 (1983).

19) Kono M., Sasatsu M., Aoki T., Noguchi N., Agric. Biol. Chem., 48, 821-822 (1984).

20) Noguchi N., Katayama J., Biol. Pharm. Bull., 21, 191-193 (1998).

21) Lovett P. S., Ambulos N. P. Jr., Mulbry W., Noguchi N., Rogers E. J., J. Bacteriol., 173, 1810-1812 (1991).

22) Taguchi A., Hamada K., Kotake M., Shiozuka M., Nakaminami H., Pillaiyar T., Takayama K., Yakushiji F., Noguchi N., Usui T., Matsuda R., Hayashi Y., ChemMedChem, 9, 2233-2237 (2014).

23) Kono M., Ohmiya K., Kanda T., Noguchi N., O'Hara K., FEMS Microbiol. Lett., 40, 223228 (1987).

24) Ohmiya K., Tanaka T., Noguchi N., O’Hara K., Kono M., Gene, 78, 377-378 (1989) .

25) Sasatsu M., Shibata Y., Noguchi N., Kono M., FEMS Microbiol. Lett., 72, 109-113 (1992).

26) Noguchi N., Hase M., Kitta M., Sasatsu M., Deguchi K., Kono M., FEMS Microbiol. Lett., 172, 247-253 (1999).

27) Noguchi N., Tamura M., Narui K., Wakasugi K., Sasatsu M., Biol. Pharm. Bull., 25, 11291132 (2002). 
28) Noguchi N., Okada H., Narui K., Sasatsu M., Microb. Drug Resist., 10, 197-203 (2004).

29) Noguchi N., Suwa J., Narui K., Sasatsu M., Ito T., Hiramatsu K., Song J. H., J. Med. Microbiol., 54, 557-565 (2005).

30) Narui K., Noguchi N., Sasatsu M., Jpn. J. Pharm. Health Care Sci., 29, 279-286 (2003).

31) Narui K., Takano M., Noguchi N., Sasatsu M., Biol. Pharm. Bull., 30, 585-587 (2007).

32) Nakaminami H., Noguchi N., Sasatsu M., Antimicrob. Agents Chemother., 54, 41074111 (2010) .

33) Paulsen L. T., Brown M. H., Littlejohn T. G., Mitchell B. A., Skurry R. A., Proc. Natl. Acad. Sci. USA, 93, 3630-3635 (1996).

34) Miyajima E., Harada D., Nakaminami H., Kitamura Y., Tamura T., Kawakubo T., Noguchi N., Microb. Drug Resist., 25, 10321040 (2019).

35) Horikawa S., Tadasa N., Narui K., Noguchi N., Sasatsu M., Jpn. J. Pharm. Health Care Sci., 34, 1017-1022 (2008).

36) Narui K., Noguchi N., Matsunaga N., Namiki Y., Yamanaka Y., Kumaki Y., Suwa J., Nasu Y., Koyama M., Okuyama K., Utsumi K., Takazawa K., Wakasugi K., Sasatsu M., J. Hosp. Infect., 73, 24-33 (2009).

37) Watanabe K., Nakaminami H., Azuma C., Tanaka I., Nakase K., Matsunaga N., Okuyama K., Yamada K., Utsumi K., Fujii T., Noguchi N., Biol. Pharm. Bull., 39, 18681875 (2016).

38) Miyamatsu H., Kanno Y., Sekine Y., Kobayashi H., Hasegawa T., Koyano M., Hashimoto M., Noguchi N., Sasatsu M., Abe M., Akashi T., Jpn. J. Pharm. Health Care Sci., 33, 30-35 (2007).

39) Watanabe K., Shioura M., Nakaminami H., Sasatsu M., Noguchi N., Jpn. J. Pharm. Health Care Sci., 39, 304-308 (2013) .

40) Tanaka I., Watanabe K., Nakaminami H., Azuma C., Noguchi N., Yakugaku Zasshi, 134, 1219-1225 (2014).

41) Noguchi N., Ohashi T., Shiratori T., Narui K., Hagiwara T., Ko M., Watanabe K., Miyahara T., Taira S., Moriyasu F., Sasatsu M., J. Gastroenterol., 42, 346-351 (2007).

42) Noguchi N., Fukuzawa M., Wajima T., Yokose K., Suzuki M., Nakaminami H.,
Kawai T., Moriyasu F., Sasatsu M., J. Infect. Public Health, 11, 39-42 (2018).

43) Noguchi N., Nakaminami H., Nishijima S., Kurokawa I., So H., Sasatsu M., J. Clin. Microbiol., 44, 2119-2125 (2006).

44) Takadama S., Nakaminami H., Aoki S., Akashi M., Wajima T., Ikeda M., Mochida A., Shimoe F., Kimura K., Matsuzaki Y., Sawamura D., Inaba Y., Oishi T., Nemoto O., Baba N., Noguchi N., J. Infect. Chemother., 23, 800-803 (2017).

45) Ito A., Nakaminami H., Fujii T., Utsumi K., Noguchi N., J. Med. Microbiol., 64, 745-751 (2015).

46) Harada D., Nakaminami H., Miyajima E., Sugiyama T., Sasai N., Kitamura Y., Tamura T., Kawakubo T., Noguchi N., J. Infect. Chemother., 24, 563-569 (2018).

47) Nakaminami H., Takadama S., Ito A., Hasegawa M., Jono C., Noguchi M., Shoshi M., Wajima T., Fujii T., Maruyama H., Sakamoto H., Ito Y., Okamoto S., Masaki Y., Tsuchiya K., Nishinarita S., Noguchi N., J. Med. Microbiol., 67, 769-774 (2018).

48) Takadama S., Nakaminami H., Sato A., Shoshi M., Fujii T., Noguchi N., Clin. Microbiol. Infect., 24, 1211.e1-1211.e7 (2018).

49) Takadama S., Nakaminami H., Takii T., Noguchi N., Diagn. Microbiol. Infect. Dis., 94, 86-87 (2019).

50) Takadama S., Yamagishi Y., Nakaminami H., Morishima T., Deie M., Mikamo H., Noguchi N., J. Infect. Chemother., 25, 212-214 (2019) .

51) Takadama S., Nakaminami H., Kaneko H., Noguchi N., J. Antimicrob. Chemother., 75, 3131-3134 (2020).

52) Kobayashi T., Nakaminami H., Ohtani H., Yamada K., Nasu Y., Takadama S., Noguchi N., Fujii T., Matsumoto T., J. Infect. Chemother., 26, 76-81 (2020).

53) Yokomori R., Tsurukiri J., Moriya M., Yamanaka H., Kobayashi T., Nakaminami H., Takadama S., Noguchi N., Matsumoto T., Arai T., JMA J., 3, 78-82 (2020) .

54) Moriya M., Tsurukiri J., Nakaminami H., Yamanaka H., Kobayashi T., Tsubouchi N., Yokomori R., Takadama S., Noguchi N., Matsumoto T., Arai T., J. Infect. 
Chemother., 26, 862-864 (2020).

55) Hayashi N., Akamatsu H., Iwatsuke K., Ohmori R., Uenaka C., Kurokawa I., Kono K., Kobayashi M., Tanioka M., Furukawa F., Komura M., Yamazaki O., Yamazaki T., Yamamoto Y., Miyaji Y., Kawashima M., Jpn. J. Dermatol., 126, 1261-1302 (2017) .

56) Nakase K., Hayashi N., Akiyama Y., Aoki S., Noguchi N., J. Dermatol., 44, 1248-1254 (2017).

57) Nakase K., Nakaminami H., Takenaka Y., Hayashi N., Kawashima M., Noguchi N., J. Med. Microbiol., 63, 721-728 (2014).

58) Nakase K., Aoki S., Sei S., Fukumoto S., Horiuchi Y., Yasuda T., Tanioka M., Sugai J., Huh W.-K. W., Kakuta M., Nomoto M., Shimada T., Watanabe M., Kobayashi M., Murakami S., Takeo C., Tsubouchi R., Hayashi N., Noguchi N., J. Dermatol., 47,
863-869 (2020).

59) Aoki S., Nakase K., Nakaminami H., Wajima T., Hayashi N., Noguchi N., Anitimicrob. Agents Chemoter., 64, e01810-19 (2020).

60) Wajima T., Anzai Y., Yamada T., Ikoshi H., Noguchi N., PLoS One, 11, e0167335 (2016).

61) Yamada T., Wajima T., Nakaminami H., Kobayashi K., Ikoshi H., Noguchi N., BMC Complement. Altern. Med., 16, 463 (2016).

62) Maezawa Y., Nakaminami H., Takadama S., Hayashi M., Wajima T., Nakase K., Yamada T., Ikoshi H., Noguchi N., PLoS One, 14, e0214470 (2019).

63) Nakase K., Tashiro A., Yamada T., Ikoshi H., Noguchi N., J. Dermatol., 46, 308-313 (2019).

64) Wajima T., Kinugawa R., Yamada T., Ikoshi H., Noguchi N., Pharmacology, 103, 221-227 (2019). 